\title{
IN (PARTIAL) DEFENSE OF STRICT LIABILITY IN CONTRACT
}

\begin{abstract}
Robert E. Scott*
Many scholars believe that notions of fault should and do pervade contract doctrine. Notwithstanding the normative and positive arguments in favor of a fault-based analysis of particular contract doctrines, I argue that contract liability is strict liability at its core. This core regime is based on two key prongs: (1) the promisor is liable to the promisee for breach, and that liability is unaffected by the promisor's exercise of due care or failure to take efficient precautions; and (2) the promisor's liability is unaffected by the fact that the promisee, prior to the breach, has failed to take cost-effective precautions to reduce the consequences of nonperformance. I offer two complementary normative justifications for contract law's stubborn resistance to consider fault in either of these instances. First, I argue that there are unappreciated ways in which courts' adherence to strict liability doctrine at the core of contract reduces contracting costs. In addition, I argue that a strict liability core best supports parties' efforts to access informal or relational modes of contracting, especially where key information is unverifiable.
\end{abstract}

“Contract liability is strict liability."

- Second Restatement of Contracts

\section{INTRODUCTION}

The Restatement's oft-quoted assertion about the nature of contract liability is one of the most imprecise generalizations ever made about the common law of contract. Numerous scholars have pointed out that, in fact, there are many notions of fault that infuse contract law, ranging from prescriptions against intentional "bad behavior," to assessments of the reasonableness of an actor's behavior in assessing both liability and damages. But while there are indeed many "fault lines" in contract, 'speaking at

* $\quad$ Alfred McCormack Professor of Law and Director, Center for Contract and Economic Organization, Columbia University.

1. George M. Cohen, The Fault Lines in Contract Damages, 80 VA. L. REv. 1225 (1994) [hereinafter Cohen, Fault Lines]; George M. Cohen, The Fault That Lies Within Our Contract Law, 107 Mich. L. Rev. 1445 (2009) [hereinafter Cohen, Fault Within Contract Law]; George M. Cohen, The Negligence-Opportunism Tradeoff in Contract Law, 20 HofSTRA L. Rev. 941 (1992). 
that level of generality has little analytic purchase. ${ }^{2}$ In short, from a distance the fault lines in contract appear broken and indistinct.

In this Article, I propose to defend the notion of strict liability that lies at the core of the Restatement's claim. By its terms, the Restatement does not rule out fault-based considerations for claims based on promissory estoppel, fraud, bad faith, mistake, excuse or a host of other issues. But the availability of these principles only in select circumstances justifies a core no-fault regime. ${ }^{3}$ This core regime is based on two key prongs: (1) the promisor is liable to the promisee for breach, and that liability is unaffected by the promisor's exercise of due care or failure to take efficient precautions; and (2) the promisor's liability is unaffected by the fact that the promisee, prior to the breach, has failed to take cost-effective precautions to reduce the consequences of nonperformance. ${ }^{4}$ In terms of the Restatement conception, then, contract law is strict liability without a contributory negligence defense.

Notwithstanding the many illustrations of fault lines in contract, the Restatement's assertion, as limited above, is descriptively accurate. The core of contract law as applied in the courts is a no-fault regime. This is so even though theorists mount powerful arguments on efficiency grounds for a costbenefit analysis of promisor and promisee behavior in particular cases, and even though contract doctrine appears to invite just such an analysis. For example, if the promisor carelessly fails to take efficient precautions ex ante that result in breach ex post, the "willful breach doctrine" invites courts to increase damages to deter such inefficient behavior. Similarly, if the promisee fails to take efficient precautions prior to the breach that would reduce or eliminate losses, the mitigation principle invites courts to apply a "contributory negligence" bar to recovery. However, a large sample of cases shows that courts decline to employ the willful breach doctrine to deter an inefficient breach. And despite evidence that the promisee has failed to take precautions prior to breach that would have reduced losses, courts adhere strictly to the rule that the promisee's mitigation responsibility is not triggered until the promisor breaches.

The courts' reluctance to adopt a comparative fault standard in assessing the core question of liability for breach is all the more surprising given that comparative fault principles are found elsewhere in contract law, most notably in the doctrines of unjust enrichment and unilateral mistake. ${ }^{5}$ Viewed in this light, the question is not why contract law fails to acknowledge explicitly the many different fault principles that it embraces implicitly. Rather,

2. See Richard Craswell, When Is a Willful Breach "Willful"? The Link Between Definitions and Damages, 107 Mich. L. REv. 1501, 1502-04 (2009) (criticizing Cohen and others for lack of clarity and precision in analyzing different fault-based notions of contract).

3. Restatement (SeCOND) of Contracts ch. 11, introductory note, at 309-12 (1981).

4. See infra Part I.

5. The doctrine of unjust enrichment and the doctrine of unilateral mistake both have compound liability rules that hinge on the "reason to know" standard. For unjust enrichment, see Day v. Caton, 119 Mass. 513 (1876); for unilateral mistake, see Restatement (SECOND) of ConTRACTs $\S 153(b)$. 
the puzzle is why courts adhere to a no-fault regime at the core of contract liability even though contract doctrine invites them to consider fault in other instances.

In Part I of this Article, I set out the case that courts are committed to a strict liability regime at what I call the "core" of contract law. This Part focuses on the evidence of strict liability as demonstrated by (a) courts' reluctance to use the willful breach doctrine to deter inefficient breach by promisors, and (b) courts' reluctance to use the mitigation principle to deter inefficient overreliance by promisees. In Part II, I offer two complementary normative justifications for contract law's stubborn resistance to fault principles at its core. I argue that there are unappreciated ways in which courts' adherence to strict liability doctrine reduces contracting costs. In addition, I argue that a strict liability core best supports parties' efforts to access informal or relational modes of contracting, especially where key information is unverifiable. I conclude, therefore, that both autonomy and efficiency values support the claim that commercial parties will prefer strict liability rules to fault-based rules for assessing performance and the response to nonperformance.

\section{The Strict Liability Core of Contract LaW}

\section{A. The Promisor's Behavior: The Willful Breach Doctrine}

Among the many debates about fault in contract law, one principle remains unchallenged: a promisor is strictly liable for defective performance or nonperformance despite her exercise of due care. Even the most fervent adherents of fault in contract law concede that the law always applies this rule strictly. ${ }^{6}$ Thus, the promisee does not have to prove that the promisor failed to take cost-effective precautions against breach. ${ }^{7}$ Nor, for that matter, can the promisor escape liability by showing that the breach was caused by exogenous factors beyond her control. ${ }^{8}$

But there is a doctrine in contract law that invites courts to adjust liability or damages if the promisor's breach was "willful." Courts have attached this doctrine primarily to the choice of damage measures in cases involving breach of a contract for services. In such cases, promisees commonly sue for the "cost of completion"- of purchasing a substitute performance in the market. However, the cost of completion sometimes exceeds the gain that the seller's performance would have produced. This problem usually occurs in construction contexts. In Jacob \& Youngs v. Kent, for example, the contractor deviated from the agreed-upon performance in an apparently minor way, but the costs of remedying that defect were much greater than the

6. Cohen, Fault Lines, supra note 1, at 1238.

7. Id.

8. This statement must be qualified to the extent that the promisor can establish an excuse owing to the fact that the risk in question was not allocated in the contract. 
reduction in property value that the deviation had caused. ${ }^{9}$ Similarly, in Peevyhouse v. Garland Coal \& Mining Co., a lessee agreed to restore the lessor's property after the lessee had used it, but the costs of restoration turned out to be much higher than the resultant increase in property value. ${ }^{10}$ In cases like these, where repair involves unreasonable destruction of the contractor's work, or the cost of completion is grossly disproportionate to the benefit obtained, the owner can recover only the diminished market value on the ground that the standard remedy would produce "economic waste."11

There is substantial uncertainty, however, as to the appropriate circumstances for applying the "economic waste" doctrine. A key doctrinal prerequisite is the finding that the contractor has substantially performed the contract in good faith and that the breach was not "willful.". In both of the celebrated cases noted above, the court declined to find fault with the promisor's breach. In Jacob \& Youngs, Justice Cardozo invoked the economic waste doctrine to limit the owners' damage award to the diminution in value caused by the breach. He found (at least implicitly) that the contractor's breach was accidental and not willful. In Peevyhouse, the majority did not address the willful breach doctrine directly, but Justice Irwin dissented on the ground that the breach "was wilful and not in good faith."13 Thus, the majority at least implicitly rejected application of the willful breach doctrine to the facts in the record.

To be sure, the precise behavior intended to be captured by the willful breach doctrine is unclear. ${ }^{14}$ However, the concept should be sufficiently capacious to embrace "inefficient behavior" by the promisor. By this standard, a breach is willful when the promisor fails to take cost-effective precautions in performing a contract that is ex ante efficient and then breaches the contract to avoid incurring substantial losses. In using this standard to evaluate the actions of promisors in cases such as Jacob \& Youngs and Peevyhouse, it is important to recognize that the promisees in such cases will have prepaid for the service in a master contract. Prepayment is often ignored by courts and commentators because, in such a contract, the services are bundled together and are not separately priced. For example, the royalty on the mineral lease in a case such as Peevyhouse is

9. 129 N.E. 889 (N.Y. 1921).

10. 382 P.2d 109 (Okla. 1962). In Peevyhouse, the diminished market value was $\$ 300$ while the cost of completion was estimated to be $\$ 29,000$. Id. at 112 .

11. See, e.g., Gerodetti v. Broadacres, Inc., 363 So. 2d 265, 267-68 (Miss. 1978); Johnson v. Black Bros., Inc., 879 So. 2d 525, 527 (Miss. Ct. App. 2004).

12. As Cardozo famously stated, "the willful transgressor must accept the penalty of his transgression." Jacob \& Youngs, 129 N.E. at 891.

13. Peevyhouse, 382 P.2d at 115 (Irwin, J., dissenting).

14. See Craswell, supra note 2, at 1502 (" "The word ... "wilful”. . . is seldom accompanied by any discussion of its meaning or classification of the cases that should fall within it." (quoting 5 Arthur Linton Corbin, Corbin on Contracts § 1123 (1951))); Steve Thel \& Peter Siegelman, Wilfullness Versus Expectation: A Promisor-Based Defense of Willful Breach Doctrine, $107 \mathrm{MICH}$. L. REv. 1517, 1525-26 (2009) (arguing that the willful breach doctrine is "largely epiphenomenal"). 
smaller if the mining company agrees to restore the land at the end of the lease term, but rarely, if ever, is there an explicit "subprice" for the agreement to restore. Likewise, the cost of constructing a building is seldom disaggregated into separate prices for the promise to install the plumbing and the promise to correct defective work. Yet, no one would claim that the mining lessee agreed to restore for nothing, or that the building contractor did not charge for nonconforming plumbing. ${ }^{15}$

Prepayment reduces the incentives for the promisor to take precautions ex ante that would reduce the ex post cost of completion. Promisors such as the contractor in Jacob \& Youngs and the mining company in Peevyhouse can sometimes reduce the cost of performance below the promisee's value by taking precautions between the time of contract and the time of completion. But a prepaid promisor's incentive to invest efficiently in cost reduction is materially reduced if her damage exposure for failing to invest is capped by the diminished value measure.

A finding of fault based on "inefficient behavior" in these situations is appropriate if four key conditions are satisfied: First, the promisor is able to take a precaution during the course of performance that reduces the expected cost of the contractually required service below its expected value to the promisee; Second, the promisee is an imperfect monitor and is unlikely to detect the promisor's lack of precaution; Third, the promisee may never (or only later) discover the promisor's failure to take precautions, and; Fourth, the promisor is able to perform the contractually required service ex post, albeit at a much more expensive price. Where these conditions are satisfied, the economic waste rule should not be applied: restricting promisees' awards to diminished market value creates an incentive for sellers not to take the efficient precaution. Rather, courts should invoke the willful breach doctrine: an award of cost-of-completion damages creates a positive incentive for sellers to take the efficient precaution. ${ }^{16}$ Cost-of-completion damages in such a case are an efficient deterrent against this moral hazard.

The question, then, is whether the contractor's behavior in Jacob \& Youngs sufficiently satisfied the "inefficient behavior" test to justify invoking the willful breach doctrine and considering fault in the assessment of damages. Virtually all the ensuing commentary has accepted Cardozo's characterization of the contractor's behavior in Jacob \& Youngs as accidental and has justified the nonwillful characterization of the breach. ${ }^{17}$

15. Alan Schwartz \& Robert E. Scott, Market Damages, Efficient Contracting, and the Economic Waste Fallacy, 108 CoLum. L. REv. 1610 (2008). The standard construction contract contains a separate promise by the contractor to correct any defective construction. This promise remains binding even after substantial performance of the contract. See e.g., AMERICAN INSTITUTE of ARChitects, AIA Document A201-1997: General Conditions of the Contract For CoNSTRUCTION (1997).

16. This argument is formally set out in Schwartz \& Scott, supra note 15, at 1652-57.

17. See Craswell, supra note 2, at 1502 ("The builder in Kent used the wrong brand of pipe, apparently by accident ...."); see also Patricia H. Marschall, Willfulness: A Crucial Factor in Choosing Remedies for Breach of Contract, 24 ARIz. L. REv. 733, 743(1982). But see Thel \& Siegelman, supra note 14, at 1526-27 (characterizing the contractor's behavior as negligent but justifying the result on other grounds). 
Unfortunately, however, that characterization appears to be false. The extraordinary costs of completion in Jacob \& Youngs resulted from the contractor's failure to inspect the pipe to ensure that it complied with the contract specifications. In dissent, Justice McLaughlin recited the key facts from the record and concluded that the failure to inspect was "due to gross neglect." 18 The record in Jacob \& Youngs thus shows that each of the four conditions supporting a finding of inefficient behavior was satisfied: ${ }^{19}$

There was (1) an apparently efficient precaution-checking the pipe as it was delivered to insure that it met contract specifications; (2) evidence that the owner, through his architect, was an imperfect monitor (he was able conveniently to check only the first installment of pipe but not the remainder); (3) difficulty in discovering the unsatisfactory performance because most of the pipe was embedded in the walls of the house; and (4) performance that was inefficient ex post: The high cost of removal caused the ex post market price of performance to exceed the [diminished market value] by so much as likely to exceed the buyer's value from performance. ${ }^{20}$

An analysis of the facts in Peevyhouse supports the same conclusion: the breach was a result of the mining company's failure to take ex ante precautions, and a fault-based analysis should have invoked the willful breach doctrine. As Judith Maute has shown, the mining company in Peevyhouse could have stripped the land with restoration costs in mind. ${ }^{21}$ Also, the plaintiff, Garland, admitted at trial that (1) the owners had insisted that the regrading provisions be included in the contract; (2) they would not agree to the coal-mining lease unless the promise to regrade was included; (3) heavy rains caused the plaintiff to postpone the promised remedial work; and (4) in the interim, plaintiff relocated the grading equipment to another profitable site and decided not to return to complete the remedial work. ${ }^{22}$

In short, declining to apply the willful breach doctrine and restricting the promisee to the diminished-value measure in the contexts these cases exemplify is inefficient. This inference is supported by a more systematic examination of the case law. In order to evaluate how contemporary American courts treat economic waste claims, I recently analyzed a sample of 110 cases, most of which were litigated in the past two decades. ${ }^{23}$ In twenty-nine cases, the courts were faced with the question of the appropriate

18. Jacob \& Youngs, Inc. v. Kent, 129 N.E. 889, 892 (McLaughlin, J., dissenting) (“[N]o examination ... was made by the plaintiff, the subcontractor, defendant's architect, or anyone else, of any of the pipe except the first delivery, until after the building had been completed.").

19. Note that we must assume, per Cardozo, that the failure to install the contract-specified pipe was, in fact, a breach. This assumption is supported in the case by the architect's refusal to give his certificate.

20. Schwartz \& Scott, Market Damages, supra note 15, at 1654 n.108.

21. See Judith L. Maute, Peevyhouse v. Garland Coal \& Mining Co. Revisited: The Ballad of Willie and Lucille, 89 Nw. U. L. REv. 1341, 1429 (1995).

22. See id. at 1413.

23. Schwartz \& Scott, supra note 15 , at 1624-34. 
measure of damages when the evidence showed that the cost to complete would greatly exceed the value of performance to the plaintiff. ${ }^{24}$ Nineteen cases had facts that were sufficiently clear to permit an inference that the seller could have taken cost-effective precautions to reduce the cost of performance. ${ }^{25}$ In these cases, where the sellers' actions likely would have reduced costs, the buyers' capacity to monitor was also likely imperfect: they were mostly amateurs, and they could not constantly be on-site. As discussed above, in cases such as these it is efficient for courts to award cost-of-completion damages, even where the ex post cost of performance significantly exceeds the buyer's ex post valuation. Such an award is efficient, as it induces the seller to take the precaution that would forestall the excess costs. Yet, in only one of the thirty cases did a court apply the willful breach doctrine and award the larger damages measure. ${ }^{26}$

The evidence from Jacob \& Youngs, Peevyhouse, and their progeny points in a single direction. Courts continue to follow the strict liability principle that the promisor's behavior is irrelevant to the issues of liability and damages. In particular, courts decline the open invitation of the willful breach doctrine to apply fault-based principles in cases where strong arguments suggest that the breach was inefficient and should have been deterred. Before trying to justify this surprising conclusion, I next examine the second prong of the core strict liability idea: that the promisee's behavior prior to the breach is irrelevant to questions of liability or damages.

\section{B. The Promisee's Behavior: The Mitigation Principle}

Common law courts have consistently held that a promisee need not take steps to avoid losses so long as the promisor has not clearly and definitively repudiated the contract. ${ }^{27}$ This rule limits the ability of courts to encourage both parties to take cost-effective precautions that will reduce the expected losses from a contract breach. ${ }^{28}$ Moreover, it is well established that, absent a legal restraint on the promisee's reliance actions, the promisee will overrely under an expectation damages default rule. ${ }^{29}$ These inefficiencies can be

24. Id. at $1625-27$.

25. Id. at 1659 \& n. 123.

26. Roudis v. Hubbard, 574 N.Y.S.2d 95 (App. Div. 1991) (applying cost of completion where contractor intentionally omitted styrofoam insulation and footing drains required by the plans).

27. See, e.g., S. Nat'l Bank of Houston v. TRI Fin. Corp., 317 F. Supp. 1173, 1185 (S.D. Tex. 1970), aff'd in part, rev'd in part sub nom. S. Nat'l Bank of Houston v. Crateo, Inc., 458 F.2d 688 (5th Cir. 1972) ("Defendant had neither breached nor indicated an intention to do so; having not yet been injured by any breach of defendant's, plaintiff had no damages to mitigate.").

28. The classic article is Robert Cooter, Unity in Tort, Contract, and Property: The Model of Precaution, 73 CAL. L. Rev. 1, 11-19 (1985). See also Richard Craswell, Precontractual Investigation as an Optimal Precaution Problem, 17 J. Legal Stud. 401 (1988); Charles J. Goetz \& Robert E. Scott, The Mitigation Principle: Toward a General Theory of Contractual Obligation, 69 VA. L. REv. 967, 989-95 (1983).

29. Under an award of full expectancy, the promisee will recover her full valuation, and thus she is motivated to invest in the subject matter of the contract until her marginal gain equals her 
moderated, however, by careful application of the rules governing anticipatory repudiation. If promisors repudiate as soon as they are aware of events that will ultimately lead to nonperformance, they can, at least in theory, induce the promisee to mitigate sooner rather than later.

A comparative fault analysis, therefore, should focus on the rules governing anticipatory repudiation: the more likely that the promisee's behavior is contributing to the losses from breach, the more likely a court should be (1) to find that the actions of the promisor constitute a repudiation of the contract, and (2) to invoke at that time the doctrine of avoidable consequences and the promisee's mitigation responsibility. By interpreting anticipatory repudiation rules in this way, courts could motivate parties to avoid or reduce the breach costs that would otherwise result if the promisee were allowed to delay mitigation until the time of performance.

To see this, consider an example in which Adam agrees on July 1 to deliver an air conditioning unit to Christy on December 1 at a cost of $\$ 500,000 .^{30}$ Assume that an explosion in Adam's plant on September 1 causes a two-month delay in delivery that will cost Christy $\$ 100,000$. Suppose, however, that if Adam informs Christy on September 1 of his inability to meet the contract deadline, Christy can redesign the building under construction to accommodate an air conditioning unit that is equivalent in quality but differently designed. Christy's total losses due to Adam's breach would then be only $\$ 40,000$-i.e. the $\$ 20,000$ additional price of the substitute air conditioner plus the $\$ 20,000$ additional cost to redesign the building. Adam would obviously prefer limiting his maximum loss to $\$ 40,000$ by having Christy redesign her building. By repudiating on September 1, at the time of the plant explosion, Adam would hope to induce Christy immediately to mitigate her damages by making the necessary adjustments.

The doctrine of anticipatory repudiation thus can be used to extend the duty of mitigation to a period before the time for performance has expired. Because it potentially enables the parties to avoid wasteful actions taken in reliance on performance, applying the doctrine in this way brings actual contracts closer to the ideally efficient contract, one which would require parties to make all cost-effective adjustments to events occurring after the contract was formed.

But courts have been reluctant to require mitigation at the time of repudiation. The common law rule remains well established: the promisee can either seek damages at the time of repudiation or wait until the time for performance and recover market damages at that later date. ${ }^{31}$ As a result,

marginal cost. But the promisee does not consider that performance would be inefficient in some ex post states of the world. In these states, the promisee's investment is a social waste. See, e.g., William P. Rogerson, Efficient Reliance and Damage Measures for Breach of Contract, 15 RAND J. ECON. 39, 47 (1984) (concluding that under expectation damages buyers will choose a greater-thanefficient level of reliance).

30. The discussion that follows draws on Robert E. Scott \& Jody S. Kraus, Contract LAW AND THEORY 815-18 (4th ed. 2007).

31. E.g., Reliance Cooperage Corp. v. Treat, 195 F.2d 977 (8th Cir. 1952); Mo. Furnace Co. v. Cochran, 8 F. 463 (C.C.W.D. Pa. 1881). 
promisees operating under the common law rule are free to exacerbate their damages by waiting until the time for performance to mitigate. And when promisees exercise this option, they undermine the possibility of mutually beneficial postcontract adjustments. The common law rule thus seems inconsistent with the fault-based, cost-benefit analysis embodied in the doctrine of avoidable consequences. Returning to our example above, giving Christy the option of waiting beyond the time of repudiation is inefficient because she will not internalize the cost of delay to Adam. Moreover, she will be motivated to wait as long as she can since she retains any benefits from a declining market while Adam must bear all the costs. ${ }^{32}$

\section{Summary}

As the above discussion has shown, in cases where courts are directly asked to consider the relevance of promisor and promisee behavior in assessing the core questions of liability and damages, the strict liability regime announced in the Restatement is alive and well. To be sure, that these core questions remain grounded in a system of strict liability does not undermine familiar claims that elsewhere contract embraces fault-based notions. But it does deepen the puzzle as to why those fault lines have failed to penetrate the two core questions: will the promisor's liability be increased if it appears that breach was caused by her inefficient behavior, and will the promisee's recovery be diminished by evidence that his inefficient behavior contributed significantly to the quantum of loss? In both cases, the answer at common law and in contemporary litigation is a clear "no." In the next Part, I ask whether this rejection of a fault-based system at the core of contract can be justified.

\section{The Normative CASE for Strict Liability}

The normative case for strict liability rests on two complementary arguments. Both are based on the claim that commercially sophisticated parties prefer strict liability rules over fault-based rules, especially at the core of contract. ${ }^{33}$ These arguments center on the revealed preference of commercial parties for precise or bright-line rules over broad standards and on a revealed preference for party autonomy in selecting precisely when and where standards are preferable to rules. ${ }^{34}$ In the first case, the preference for autonomy in selecting between rules and standards permits parties to optimize

32. The Uniform Commercial Code permits the promisee to wait a "commercially reasonable time" following the repudiation, and thus also fails a comparative fault analysis. U.C.C. $\S 2$ 610(a) (2004).

33. In principle, the arguments outlined here might also be applied to contracts made by commercially unsophisticated parties. But defending an extension of the argument to such cases would require additional analysis to take into account a range of considerations that I do not undertake here.

34. My argument that the law properly attends to the revealed preferences of commercial parties can be supported on both efficiency and autonomy grounds. And, to be sure, moral theorists may offer other normative arguments in favor of strict liability. 
contracting costs by shifting them between the front end and the back end of the contractual process. In the second case, the preservation of formal rules offers parties the choice of improving contractual incentives by relying on informal or relational contracting as a complement to the formal contract. In this Part, I first consider the theoretical arguments that support the claim that commercial parties prefer formal rules in general and strict liability at the core of contract in particular. Thereafter, I evaluate the evidence that supports the theoretical claims.

\section{A. Contract Design and the Choice Between Rules and Standards}

Why might commercial parties prefer strict liability to a fault-based regime? One answer lies in the trade off between contracting costs and the goal of improving contractual incentives. Commercial parties will weigh front- or back-end contracting costs against the incentive gains that they produce - what George Triantis and I have referred to elsewhere as the incentive "bang" for their contracting-cost "buck."36 And they will prefer improved incentives of the sort we examined earlier only if those incentives do not generate even greater contracting costs. To understand parties' apparent preference for formal rules like strict liability, one must consider the contract-design challenges that they face in writing incomplete contracts. ${ }^{37}$

Incomplete contracts are challenging because the parties must attempt to balance two seemingly inconsistent goals. One goal is to encourage "relation-specific investments" that enhance the expected surplus from the transaction. But the commitment that is necessary to motivate surplusmaximizing specific investments will typically conflict with the goal of preserving flexibility-which is necessary to halt those transactions that prove to have insufficient net value when uncertainty is resolved.

One way to encourage initial investments is for the parties to write a contract with precise, unchanging terms or "rules," i.e., determinate outcomes that apply across the board regardless of the eventual state of the world. But because the rules are inflexible, they may not respond to what actually happens and may be inefficient ex post. ${ }^{38}$ Alternatively, if the future

35. This discussion draws on Robert E. Scott \& George G. Triantis, Anticipating Litigation in Contract Design, 115 YALE L.J. 814 (2006) [hereinafter Scott \& Triantis, Anticipating Litigation] and Robert E. Scott \& George G. Triantis, Incomplete Contracts and the Theory of Contract Design, 56 CASE W. RES. L. REv. 187 (2005).

36. Scott \& Triantis, Anticipating Litigation, supra note 35 , at 817.

37. Under conditions of uncertainty, contracts will be incomplete in the sense that information costs will make it impossible to distinguish ex ante the ex post states of the world that call for different obligations. See, e.g., Oliver Hart \& John Moore, Foundations of Incomplete Contracts, 66 REv. ECON. STUD. 115 (1999); Oliver Hart \& John Moore, Incomplete Contracts and Renegotiation, 56 Econometrica 755 (1988); Oliver D. Hart, Incomplete Contracts and the Theory of the Firm, 4 J.L. ECON. \& ORG. 119 (1988).

38. One solution is for the parties to renegotiate the contract once uncertainties are resolved. But renegotiation raises the risk of a hold up; and this, in turn, undermines the incentives for parties to make specific investments in the first place. For discussion, see Oliver Hart \& John Moore, Property Rights and the Nature of the Firm, 98 J. PoL. Econ. 1119 (1990), and Benjamin Klein, Vertical 
is very uncertain, the parties may instead emphasize the value of flexibility by drafting a contract with vague standards, i.e., "soft" terms such as those that require subsequent adjustment in good faith to new facts as they arise. But a promisor with the discretion to adjust performance is likely to choose the best alternative for him even though the self-interested choice is unlikely to be the best way to maximize the parties' joint welfare. ${ }^{39}$

In short, neither precise rules nor vague standards can, standing alone, solve the problem of incomplete contracts. Therefore, parties predictably seek to optimize total contracting costs by trading off the respective benefits and costs of commitment and flexibility. They can do this by shifting their costs between the front and back end of the contracting process. For example, when the parties agree to bright-line rules, such as the buyer's obligation to purchase a precisely specified, customized machine at a fixed price, they encourage the seller to undertake the required investment by limiting the court's authority to determine their particular performance obligations. But this strategy requires the parties to rely on mere estimates of the likelihood of future events. Alternatively, when the parties agree to a vague standard, i.e., to adjust the price of the machine in good faith as conditions subsequently require, they effectively delegate the specification of performance requirements to a court at the back end of the contracting process. This provides flexibility and allows them potentially to benefit from the court's hindsight advantage but at a cost of undermining the buyer's commitment to pay and the seller's willingness to invest. The parties thus choose between these front- and back-end specification mechanisms by comparing the benefits of ex ante commitment against the flexibility offered by the court's hindsight advantage. ${ }^{40}$

This model of contract design suggests that courts should refrain from filling contractual gaps with broad standards in cases where the parties are silent. A court may be tempted (with the encouragement of one of the parties) to see gaps and to use fault-based doctrines such as mistake, excuse, or frustration as devices for implying standards into the parties' agreement. But this is generally an error. Commercial parties can include standards in their contract at relatively low cost. They also have superior knowledge regarding the context of their contractual relationship, which provides the basis for determining the optimal mix of precise and vague terms. ${ }^{41}$ As a rule of thumb, therefore, courts are wise to assume that the absence of vague standards in commercial contracts is an instruction from the parties to focus interpretation on the precise terms of the contract.

Integration as Organizational Ownership: The Fisher Body-General Motors Relationship Revisited, 4 J.L. ECON. \& ORG. 199 (1988).

39. See Alan Schwartz \& Robert E. Scott, Contract Theory and the Limits of Contract Law, 113 YALE L.J. 541, 602-03 (2003).

40. The options available to the parties are even broader than the stark choice between rules and standards. With the aid of interpretation maxims, parties can design combinations of precise and vague terms that define more exactly the "space" within which a court has discretion in interpreting the contract. For discussion, see Scott \& Triantis, Anticipating Litigation, supra note 35, at 848-56.

41. See, e.g., Schwartz \& Scott, supra note 39, at 545. 
This preference for party autonomy in selecting what standards to use and when to use them supports the claim that commercial parties will prefer strict liability rules to broad, fault-based standards. In addition to the trade off between front- and back-end contracting costs, bright-line rules offer commercial parties the opportunity to resolve their disputes without a fullblown trial. It is plausible to believe that the more complex the factual issues in litigation, the easier it will be for one party to create disputes regarding the appropriateness of the other's behavior. Thus, litigation is likely to be more costly in a fault-based regime because the parties more frequently will have full trials. When parties weigh their contract design choices, they will not only consider the costs and gains from creating the deal initially; they will also consider the likelihood and costs of later disputes. That fault regimes increase the likelihood and cost of disputes explains why parties may prefer contracts that only crudely encourage efficient behavior but significantly reduce the contracting costs of enforcement.

\section{B. Rules v. Standards and the Choice Between Formal and Informal Enforcement ${ }^{42}$}

As suggested in the earlier discussion, contract design is not merely a matter of calculating the costs and benefits of negotiating particular terms in a contract. In addition to the front-end cost of negotiating a contract, parties must attend to the back-end problems of verifying and enforcing their respective obligations in court. A focus on the costs of verifying contractual obligations motivates parties to consider the choice between formal and informal means of enforcement.

In many instances, an agreement between two commercial parties will be self-enforcing because both parties want to earn and preserve a good reputation so as to enhance their self-esteem and future business prospects. ${ }^{43}$ Moreover, agreements will also be self-enforcing to the extent that the parties anticipate that the expected profits from future dealings are greater than the gains from breaching the existing contract. ${ }^{44}$

Even where loss of reputation and the threat of retaliation are insufficient to induce performance, powerful norms of reciprocity appear to enhance and extend the reach of informal enforcement. A substantial body of experimental evidence shows that a preference for reciprocity-i.e., the willingness to reward cooperation and to punish selfishness-can motivate

42. This discussion draws on Robert E. Scott, A Theory of Self-Enforcing Indefinite Agreements, 103 Colum. L. Rev. 1641 (2003).

43. See Schwartz \& Scott, supra note 39, at 557 (asserting reputations work well in small trading communities, where information about others' actions is common knowledge and boycotts of bad actors are readily enforced).

44. Retaliation has its limits: the threat that the other party will no longer deal with the promisor may be insufficient to induce performance if parties come to realize that the relationship is soon to terminate. See, e.g., Benjamin Klein, Why Hold-Ups Occur: The Self-Enforcing Range of Contractual Relationships, 34 ECON. INQUIRY 444 (1996). 
cooperation even in arms-length interactions between complete strangers. ${ }^{45}$ This evidence suggests that contracting parties frequently can (and do) turn to informal means of enforcement based on trust and reciprocity in addition to the desire to maintain a good reputation or the prospect of profitable future dealings. And if parties are able to rely on these informal methods of enforcement, they may be able to create contractual commitments that are at once sufficiently credible to motivate efficient investments ex ante and sufficiently flexible to ensure efficient adjustment ex post.

So, what role does (and should) legal enforcement play in a world where informal enforcement is pervasive and robust? First, note that informal enforcement generally is cheaper than formal enforcement because a party needs to expend costs only to observe the other's behavior, while formal enforcement requires additional resources in verifying that behavior to a court. Moreover, informal enforcement is often better than formal enforcement: parties can make credible promises regarding observable but nonverifiable measures of performance, thus achieving contractual objectives that may not be possible with formal enforcement. ${ }^{46}$ To be sure, there is still an important role for formal contract enforcement. Common sense tells us that relationships relying on informal enforcement can break down, and when they do, the parties will resort to costly litigation. When reciprocity breaks down in complex transactions, the courts can serve a valuable function by making factual determinations to unravel complex behaviors. ${ }^{47}$

Thus, a central question remains: how do the various means of enforcement interact with each other? The available evidence suggests that legal enforcement is often imperialistic-that an effort to superimpose legal enforcement on a regime of self-enforcement can displace or "crowd out" informal mechanisms. ${ }^{48}$ The experimental evidence of crowding out

45. This substantial body of experimental evidence shows that individuals respond cooperatively to generous acts and, conversely, punish noncooperative behavior. Moreover, individuals will repay generosity and punish selfishness even if doing so is costly and yields neither present nor future material rewards. See, e.g., Ernst Fehr \& Klaus M. Schmidt, A Theory of Fairness, Competition and Cooperation, 114 Q.J. EcoN. 817 (1999); Ernst Fehr et al., Reciprocity as a Contract Enforcement Device: Experimental Evidence, 65 Econometrica 833 (1997); David K. Levine, Modeling Altruism and Spitefulness in Experiments, 1 REv. Econ. Dynamics 593 (1998); Matthew Rabin, Incorporating Fairmess into Game Theory and Economics, 83 AM. EcoN. REv. 1281 (1993). For a review of the literature, see Ernst Fehr \& Klaus M. Schmidt, Theories of Fairness and Reciprocity-Evidence and Economic Applications 2-3 (Univ. of Zurich Inst. for Empirical Research in Econ., Working Paper No. 75, 2001).

46. Scott, supra note 42 , at 1667-72.

47. In complex interactions, a failure to cooperate may not be observable immediately, or else a cooperative response may be mistakenly interpreted as a defection from cooperative norms. Robert E. Scott, Conflict and Cooperation in Long-Term Contracts, 75 CAL. L. REv. 2005, 2050-53 (1987). A disinterested adjudicator may be in better position to sort out complex behavior, detect a breach, and, by imposing a predetermined sanction, forestall attempts by the aggrieved party to respond disproportionately. Robert E. Scott \& Paul B. Stephan, The Limits of Leviathan: CONTRACT ThEORY AND THE ENFORCEMENT OF INTERNATIONAL LAW 100 (2006).

48. A number of studies have confirmed the crowding-out hypothesis. For discussion see Scott, supra note 42, at 1688-92. Other recent experiments also show that if there is some probability of continued transactions, then legal enforcement that is limited to the verifiable dimensions of the agreement will enhance cooperation in the dimensions of the agreement that are nonverifiable. 
undermines the argument that courts should adopt a broad, fault-based approach to enforcing contracts. The understandable instinct to deter inefficient behavior may well prove counterproductive in the long run. As the evidence suggests, extending legal enforcement to the difficult-to-verify questions of willful breach and overreliance may well impair the efficacy of informal means of enforcement that rely instead on reciprocity norms.

As we have seen, common law contract doctrine has resisted the invitation to imply broad fault standards of behavior at the core of contract. Thus, if a promise falls within the core of legal enforcement, contract law fills only a few gaps, using simple, verifiable strict liability rules when it does so. ${ }^{49}$ The evidence that there are informal means of enforcing commitments that courts cannot readily verify supports this approach. The more general lesson for courts, therefore, is that an effort to judicialize notions of comparative fault and reciprocal behavior may well destroy the very informality that makes these mechanisms so effective in the absence of judicial enforcement. $^{50}$

\section{The Evidence}

While there are good theoretical reasons to believe that commercial parties prefer a strict liability regime to one based on fault, critics may argue that theoretical inferences about parties' intentions are fraught with peril. ${ }^{51}$ If commercial parties prefer a formal, strict liability regime, it may be argued, then why don't they say so?

The short answer is that they do. A common provision found in many alliance agreements is the following:

The Parties' legal obligations under this Alliance Agreement are to be determined from the precise and literal language of this Alliance Agreement and not from the imposition of state laws attempting to impose additional duties of good faith, fair dealing or fiduciary obligations that were not the express basis of the bargain at the time this Agreement was made.

The Parties are sophisticated business entities with legal counsel that have been retained to review the terms of this Alliance Agreement and the Parties represent that they have fully read this Alliance Agreement, and understand and accept its terms. ${ }^{52}$

Sergio G. Lazzarini et al., Order with Some Law: Complementarity versus Substitution of Formal and Informal Arrangements, 20 J.L. EcoN. \& ORG. 261 (2004).

49. For discussion, see Robert E. Scott, The Case for Formalism in Relational Contract, 94 Nw. U. L. Rev. 847 (2000); Robert E. Scott, The Death of Contract Law, 54 U. ToRonTo L.J. 369 (2004).

50. Robert E. Scott, A Relational Theory of Default Rules for Commercial Contracts, $19 \mathrm{~J}$. Legal STUD. 597, 615 (1990).

51. See Cohen, Fault Within Contract Law, supra note 1.

52. Alliance Agreement between E. I. du Pont de Nemours \& Co. and EarthShell Corp. (Jul. 25, 2002), available at http://contracts.onecle.com/earthshell/dupont.collab.2002.07.25.shtml. 
In addition to such anecdotal evidence from individual contracts, the available data support the strict liability theory. First, Lisa Bernstein's pioneering work shows that parties who are members of trade associationsand thus who rely on both informal or relational enforcement as well as third-party enforcement-carefully preserve formal, strict liability rules and reject broad standards in assessing performance, breach and liability. ${ }^{53}$ Bernstein argues that this regime can best be understood as a mechanism for preserving the space for both formal and informal norms to operate.

Second, recent work by Eisenberg and Miller studying choice-of-law and choice-of-forum clauses in a data set of 2865 contracts provides empirical support for the claim that commercial parties prefer the binary strict liability regime of the traditional common law. ${ }^{54}$ Specifically, their study showed that parties choose New York law in 46 percent of the contracts and New York as the forum state in 41 percent of the contracts. ${ }^{55}$ California, on the other hand, was chosen for its contract law in less than 8 percent of the contracts even though its commercial activity, as measured by the place of business of the contracting parties, was second only to New York. ${ }^{56}$

The significance of this striking differential in party preference is illuminated in a recent paper by Geoff Miller that analyzes the differences in contract law between New York and California. ${ }^{57}$ Miller's analysis confirms the conventional wisdom: New York strictly enforces bargains and displays little tolerance of efforts to balance interests ex post; California, by contrast, is far more willing to adopt fault-based considerations and to revise contracts on the grounds of fairness, equity, or public policy. As Miller concludes, "[t]he revealed preferences of sophisticated parties support arguments by Schwartz, Scott and others that formalistic rules offer superior value for the interpretation and enforcement of commercial contracts."

The theory and evidence that support the normative case for strict liability in contract are partial in two respects. First, they are partial because the theory and evidence largely apply to commercially sophisticated parties. Thus, the normative claims for strict liability have less force, if any, when applied to other areas of contract law, and particularly those that concern

53. Lisa Bernstein, Merchant Law in a Merchant Court: Rethinking the Code's Search for Immanent Business Norms, 144 U. PA. L. Rev. 1765 (1996); Lisa Bernstein, Private Commercial Law in the Cotton Industry: Creating Cooperation Through Rules, Norms and Institutions, 99 MicH. L. REv. 1724 (2001).

54. Theodore Eisenberg \& Geoffrey P. Miller, The Flight to New York: An Empirical Study of Choice of Law and Choice of Forum Clauses in Publicly-Held Companies' Contracts (N.Y.U. Ctr. For Law \& Econ., Working Paper No. 124, 2008), available at http://lsr.nellco.org/nyu/lewp/ papers/124.

55. Id. at 21, 36. Delaware was a distant second to New York, with about 15 percent of the parties choosing its law. No other state accounted for even 10 percent of the choices of law. Id. at 21 .

56. Id. at 21 .

57. Geoffrey P. Miller, Bargaining on the Red-eye: New Light on Contract Theory (N.Y.U. Ctr. For Law \& Econ., Working Paper No. 131, 2008), available at http://sr.nellco.org/nyu/lewp/ papers/131.

58. Id. at 1. 
contracts made by relatively unsophisticated parties. The case is partial in a second respect as well: strict liability in contract exists largely in a narrow domain - the primary behavior of the promisor and promisee, respectively, in the performance of the contract and in reliance on that performance. Nevertheless, the theory and evidence supporting strict liability rules within those two domains is largely unchallenged.

\section{CONCLUSION}

The claim that strict liability in contract is a myth ${ }^{59}$ faces two formidable obstacles. First, the claim is descriptively inaccurate. At the core of contractual obligations, strict liability is alive and well. If one focuses on what courts actually do, there is substantial evidence that they decline opportunities to use the willful breach doctrine to deter inefficient promisor breaches, and, in addition, they decline opportunities to deploy the mitigation principle to deter inefficient overreliance by promisees. Second, the claim is normatively problematic. Notions of autonomy and efficiency both support the claim that, in assessing performance and the response to nonperformance, commercial parties will prefer strict liability rules to fault-based rules. While the evidence is incomplete, it is nevertheless significant that the available theory and evidence point in one direction-significant enough to shift the intellectual burden of proof.

59. See Cohen, Fault Lines, supra note 1, at 1312 ("But we have already seen that strict liability is a myth."). 